\title{
Aged embankment imaging and assessment using surface waves
}

\section{David Gunn PhD}

Engineering Geophysicist, Engineering Geology, British Geological Survey, Nottingham, UK (corresponding author: dgu@bgs.ac.uk)

Ben A. J. Dashwood PhD

Engineering Geophysicist, Engineering Geology, British Geological Survey, Nottingham, UK
Paolo Bergamo PhD

Post-Doctoral Researcher, Schweizerischer Erdbebendienst, ETH Zurich, Zurich, Switzerland

Shane Donohue PhD

Lecturer in Geotechnical Engineering, School of Planning, Architecture and Civil Engineering, Queen's University Belfast, Belfast, UK

Rapid, non-intrusive surface wave surveys provide depth profiles from which ground models can be generated for use in earthwork condition assessment. Stiffness throughout earthworks controls the behaviour under static and dynamic loads, and characterising heterogeneity is of interest in relation to the stability of engineered backfill and life-cycle deterioration in aged utility and transportation infrastructure. Continuous surface wave methods were used to identify interfaces between fine- and coarse-grained fill in an end-tipped embankment along the Great Central Railway in Nottinghamshire, UK. Multichannel analysis of surface wave (MASW) methods were used to characterise subsurface voiding in a canal embankment along the Knottingley and Goole canal near Eggborough, Yorkshire. MASW methods are currently being used to study extreme weather impacts on the stability of a highplasticity clay embankment along the Gloucestershire-Warwickshire railway near Laverton. Optimal results were obtained using equipment capable of generating and detecting over wide frequency ranges.

\section{Notation}

$c^{\prime} \quad$ drained cohesion measured at effective stress: $\mathrm{kPa}$

$f$ frequency: $\mathrm{Hz}$

$f_{\mathrm{s}} \quad$ sleeve friction: $\mathrm{kPa}$

$G \quad$ small strain stiffness or shear modulus: $\mathrm{Pa}$

L spacing: $\mathrm{m}$

$L_{\mathrm{L}} \quad$ moisture content value of the liquid limit: mass ratio convention $\% \mathrm{~g} / \mathrm{g}$

$L_{\mathrm{P}} \quad$ moisture content value of the plastic limit: mass ratio convention $\% \mathrm{~g} / \mathrm{g}$

$q_{\mathrm{c}} \quad$ cone penetration resistance: $\mathrm{MPa}$

$V_{\mathrm{R}} \quad$ Rayleigh wave velocity: $\mathrm{m} / \mathrm{s}$

$V_{\mathrm{S}} \quad$ shear wave velocity: $\mathrm{m} / \mathrm{s}$

$\Delta \phi \quad$ phase differences

$\lambda_{\mathrm{R}} \quad$ wavelength of Rayleigh wave: $\mathrm{m}$

$v \quad$ Poisson's ratio (dimensionless)

$\rho_{\mathrm{b}} \quad$ bulk density: $\mathrm{kg} / \mathrm{m}^{3}$

$\phi^{\prime} \quad$ angle of friction at effective stress: ${ }^{\circ}$

\section{Introduction}

\subsection{Construction and heterogeneity of aged UK} earthworks

Much of the construction of the UK canal network started in the mid-eighteenth century at the beginning of the Industrial Revolution (Stevenson, 1886). Much railway construction followed in the nineteenth century, during the formative years of the Industrial Revolution (Skempton, 1996). The largest concentration of UK canals, roads and railways is in the South-East and around the major cities of Birmingham, Leeds, Liverpool and Manchester. Excavation of aged canal and railway cuttings commonly employed large teams of labourers using driven wedges, horse-pulled ploughs, hand tools and, on the later railways such as the Great Central, steam-powered excavators (Brees, 1841; Skempton, 1996; Stevenson, 1886). While the construction materials were influenced by the underlying geological formations, the engineering characteristics of fine-grained overconsolidated clay or weak mudstone formations favoured relatively easy excavation using these tools; hence, many aged canal and railway earthworks comprise London Clay, Oxford Clay, Gault Clay, Mercia Mudstone and Lias Clay (Reeves et al., 2006). The absence of any established practice resulted in embankment construction methods varying considerably between networks, often based on the experiences of the chief engineer. Side tipping was commonly employed in the construction of canal embankments, and railway embankments were often end tipped, both using local materials (Skempton, 1996). While modern embankments tend to be structured into wellcompacted layers, aged embankments often have poor levels of compaction, a greater variability of fill material grades and usually exhibit highly unique heterogeneity (Selig and Waters, 1994; Skempton, 1996). Earthwork assessment requires the determination of conditions important for the evaluation of performance. Soil type, moisture, stress levels and strength control problems such as plastic deformation, heave, shear failure and mud pumping, which lead to a loss of embankment level and support (Perry et al., 2003). Surface wave surveys provide a non-invasive means of assessing density and stiffness, which themselves are dependent on these soil properties and, thus, provide key earthwork condition indicators. 


\subsection{Embankment characterisation approaches and methods}

Repeated visual inspections are mostly used to identify embankment problems, essentially looking for morphological features that confirm movement and anomalous groundwater conditions (Perry et al., 2003). This approach is limited - for example because vegetation can often obscure signs of ground movement, subsurface ground and water conditions are not accessible and slopes often fail 'rapidly' without displaying visible signs of distress. Most common geotechnical monitoring approaches involve displacement measurements of embankments, often following observations of morphological features associated with instability (Dunnicliff, 2012). Surface and downhole tilt meters or extensometers are deployed to assess the displacement profile with depth. Such approaches require boreholes and are often accompanied by groundwater level measurements using piezometers. These data inform stability analyses, aid risk assessments and may contribute to remedial design. These approaches include the expense of intrusive works and implicitly accept the potential for failure, which does not honour the strict terms of 'early warning'. Indeed, a recent Department for Transport review on infrastructure resilience (DfT, 2014) highlighted the importance of maintaining climate-resilient infrastructure and specifically recommended that geotechnical asset owners should 'maintain a strong focus on trialling newly available condition monitoring technologies ... [and] improve [their] ability to identify and anticipate slopes that will fail and target remedial work as efficiently as possible' (DfT, 2014: p. 102). Consequently, remotely sensed and non-invasive surface approaches are being explored by many asset owners. Such approaches are better suited for more rapid, cost-effective network coverage designed to detect smaller-scale changes considered to be the 'precursors' to the morphological features currently used to define marginal condition. Satellite or ground-based radar (lidar), robotic total stations and photogrammetry provide high-resolution ground displacement information (Mazzanti, 2012), but still essentially confirm the morphological response to underlying subsurface property (condition) changes that form earlier phases of asset deterioration. With no standard practice and no, or very poor, 'as-built' documentation, development of conceptual models for predicting the failure modes of aged infrastructure is particularly challenging. Geophysical imaging approaches can monitor internal property (condition) changes. These are the precursors connecting surface morphological response to subsurface processes driven by climate and ageing stresses (Gunn et al., 2015a, 2016). These property change signatures offer a potential baseline against which internal condition thresholds can be identified and used as early warning of future instability.

\subsection{Embankment characterisation and imaging using surface waves}

Penetration into engineered pavements, sub-base and heterogeneous earthworks is particularly challenging; thus, invasive methods can become prohibitively time consuming and costly. Also, while useful for ground truthing, the limited sampling of invasive site investigation (SI) methods makes them unsuitable for imaging irregular heterogeneous structures. Non-invasive geophysical techniques are cost-effective and rapid, and may provide twodimensional (2D) and three-dimensional (3D) information, which makes them ideal for studying the spatial and temporal variations within assets that cannot be readily captured using discrete boreholes or other forms of geotechnical investigation alone (Bergamo et al., 2016; Chambers et al., 2014; Gunn et al., 2015a, 2016).

Surface wave surveys can be mobilised to image the volumetric distribution of shear wave velocity and, thus, map the small strain stiffness (shear modulus) throughout earthworks, from which heterogeneity can be assessed (Bergamo et al., 2016; Donohue et al., 2011; Gunn et al., 2013, 2015b; Zagyapan and Fairfield, 2000). These images can be used to assess the unique internal heterogeneity- and strength-related characteristics arising from the original tipping construction methods, or due to subgrade problems resulting from progressive deterioration. They can inform further SI design in relation to poor ground conditions and aid location of more challenging invasive methods such as pitting, cone penetration resistance testing and coring (Gunn et al., 2012; Raines et al., 2011). Rayleigh wave analysis, in particular, has been established as a reliable tool for the characterisation of the small strain stiffness (shear modulus $G$ ) of the near surface at the engineering scale (Donohue et al., 2011, 2013a; Foti, 2003). Rayleigh waves are dispersive; their phase velocity varies with wavelength and, hence, depth of investigation (Socco and Strobbia, 2004). Parametric studies (Xia et al., 1999) have shown the prevailing sensitivity of Rayleigh wave phase velocity to the shear wave velocity structure of the subsurface, so that information on shear modulus distribution can be assessed (Rucker, 2003). Also, reasonably short-term monitoring programmes by Bergamo et al. (2016) indicated distributed variation in Rayleigh wave phase velocity throughout a clay embankment to be sensitive to internal seasonal moisture variations. Such observations indicate the potential for repeat surface wave surveys to be used as a basis for long-term asset condition and deterioration monitoring - for example raising the prospects for condition matrices based directly on stiffness or its use as a proxy for consolidation, density or saturation. To this end, this paper presents three case histories to demonstrate the application, benefits and limitations of continuous surface wave (CSW) and multichannel analysis of surface wave (MASW) methods in relation to the assessment of the internal condition of aged embankments. Figure 1 shows the location of the three study sites, which include $(a)$ an end-tipped rail embankment in Nottinghamshire, (b) a side-tipped canal embankment in North Yorkshire and $(c)$ a clay rail embankment in Worcestershire.

\section{Non-invasive surface wave surveys}

\subsection{Relevance of surface waves and stiffness to} engineering characterisation

Rayleigh waves are often observed as the surface roll resulting from vertical impact on the ground. In fact, two-thirds of the total 


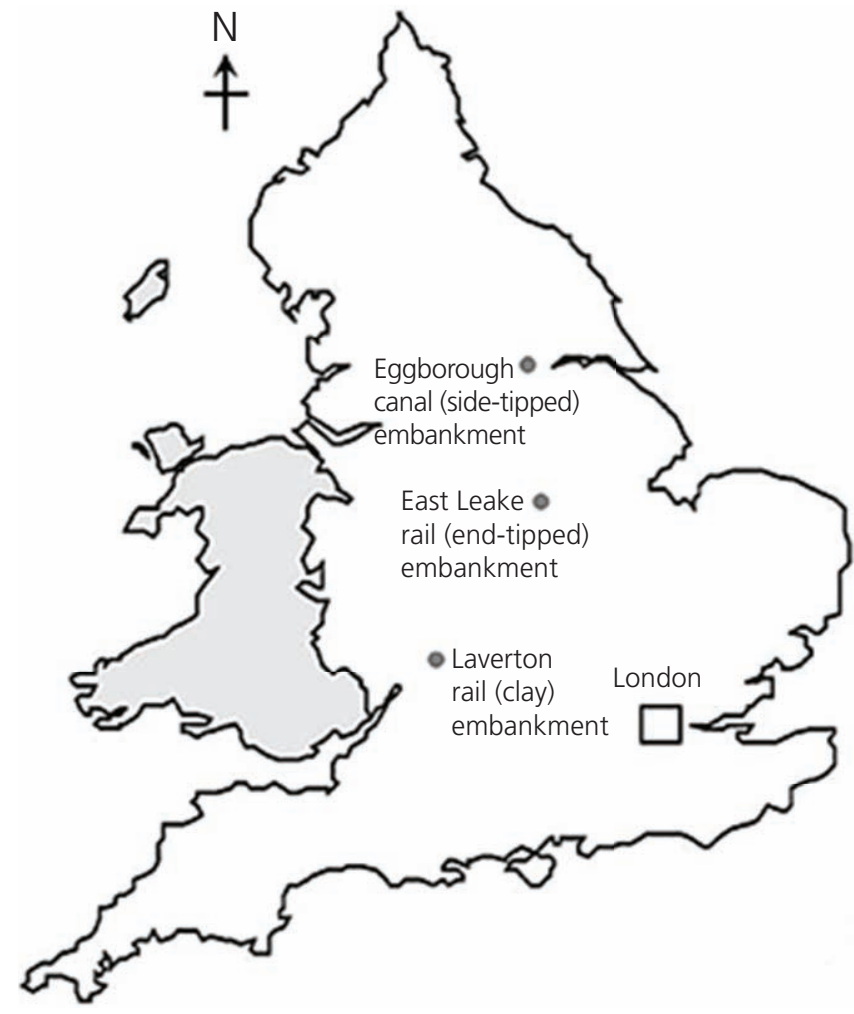

Figure 1. Map of England and Wales showing location of case study sites

seismic wave energy generated by such impact propagates as Rayleigh waves (Gunn et al., 2012; Richart et al., 1970). Rayleigh wave velocity can be derived as a fraction of the shear wave velocity for rocks and soils (Woodward et al., 2011), using

1. $V_{\mathrm{R}}=\frac{(0 \cdot 87+1 \cdot 12 v)}{(1+v)} V_{\mathrm{S}}$

where $v$ is Poisson's ratio. Poisson's ratios for rocks are commonly within the range of $0 \cdot 2-0 \cdot 3$. Soils tend to have higher Poisson's ratios around $0 \cdot 3-0 \cdot 4$, which can be even higher in very soft, fully saturated fine-grained materials, resulting in Rayleigh wave velocities between 90 and $95 \%$ of shear wave velocities. Shear wave velocity $V_{\mathrm{S}}$ is controlled by the stiffness, or the small strain shear modulus, G (Abbiss, 1981; Hight et al., 1997), and the bulk density $\rho_{\mathrm{b}}$ of the medium, given as

2. $V_{\mathrm{S}}=\sqrt{\frac{G}{\rho_{\mathrm{b}}}}$

The bulk density of the soil is the volumetric sum of the densities of the solid soil particles, porewater and the unsaturated air voids. The contribution of the air component is negligible because of its very low density, but porosity and saturation exert very significant control over both bulk density and stiffness of soils and engineered fill (Donohue et al., 2013b; Gunn et al., 2003). Stiffness is defined as the ratio of stress to strain in material undergoing deformation. Many soils exhibit viscoelastic behaviour leading to strain softening (Bardet, 1992), which results in the absolute values of stiffness at small strains $\left(<10^{-3}\right)$ generally being far greater than at larger strains. For fully saturated soils, porosity, bulk density and interparticle friction are interrelated with the way in which a soil consolidates and thus have a very significant influence on its stiffness and shear wave velocity (Gunn et al., 2003). Hardin and Richart (1963) and Richart et al. (1970) showed stiffness to be linearly dependent on void ratio for uncemented sands, and Viggiani and Atkinson (1995) showed broad linear dependence of clay stiffness on the overconsolidation ratio. In partially saturated soils, there is an additional contribution to stiffness from suctions, which Whalley et al. (2012) related to net stress and the matric potential, and Cosentini and Foti (2014) related to soil porosity and saturation by using the van Genuchten equation.

\subsection{Development of practice and modern surface wave survey field methods}

Early procedures using surface Rayleigh wave techniques for soil property testing were suggested in the 1950 s - for example Jones (1958) - but were limited by the technology then available. The procedure, called the steady-state Rayleigh method (Jones, 1958; Richart et al., 1970; Rix, 1988) used a vertically acting sinusoidal vibrator, working at a frequency $(f)$, placed on the ground surface and vertical receivers also on the ground surface, as shown in Figure 2(a). Receiver pairs were moved to locations away from the vibrator until the signals measured by them were in phase. At these positions, the distance between the receiver pairs was equivalent to the Rayleigh wavelength $\lambda_{R}$ at that particular frequency. The phase velocity of the Rayleigh surface waves was determined using the relationship

\section{3. $V_{\mathrm{R}}=f \lambda_{\mathrm{R}}$}

By changing the frequency, it is possible to construct a phase velocity-wavelength curve, also known as a Rayleigh wave dispersion curve $\left(V_{\mathrm{R}}\right.$ plotted against $\lambda_{\mathrm{R}}$; or $V_{\mathrm{S}}$ plotted against $\lambda_{\mathrm{R}}$ by way of Equation 1). This study's surveys included CSW methods, which are a variant of the steady-state Rayleigh method. CSW also utilises a controlled frequency, a vertical oscillator and a small number of low-frequency geophones (Figure 2(b)). But in this case, the receiver positions remain fixed and the wavelength at each frequency was calculated from the phase differences $\Delta \phi$ between the ground motions on successive geophones and the spacing $L$ between them (Joh, 1996; Menzies, 2001) using

4. $\lambda_{\mathrm{R}}=L \Delta \phi / 2 \pi$ 

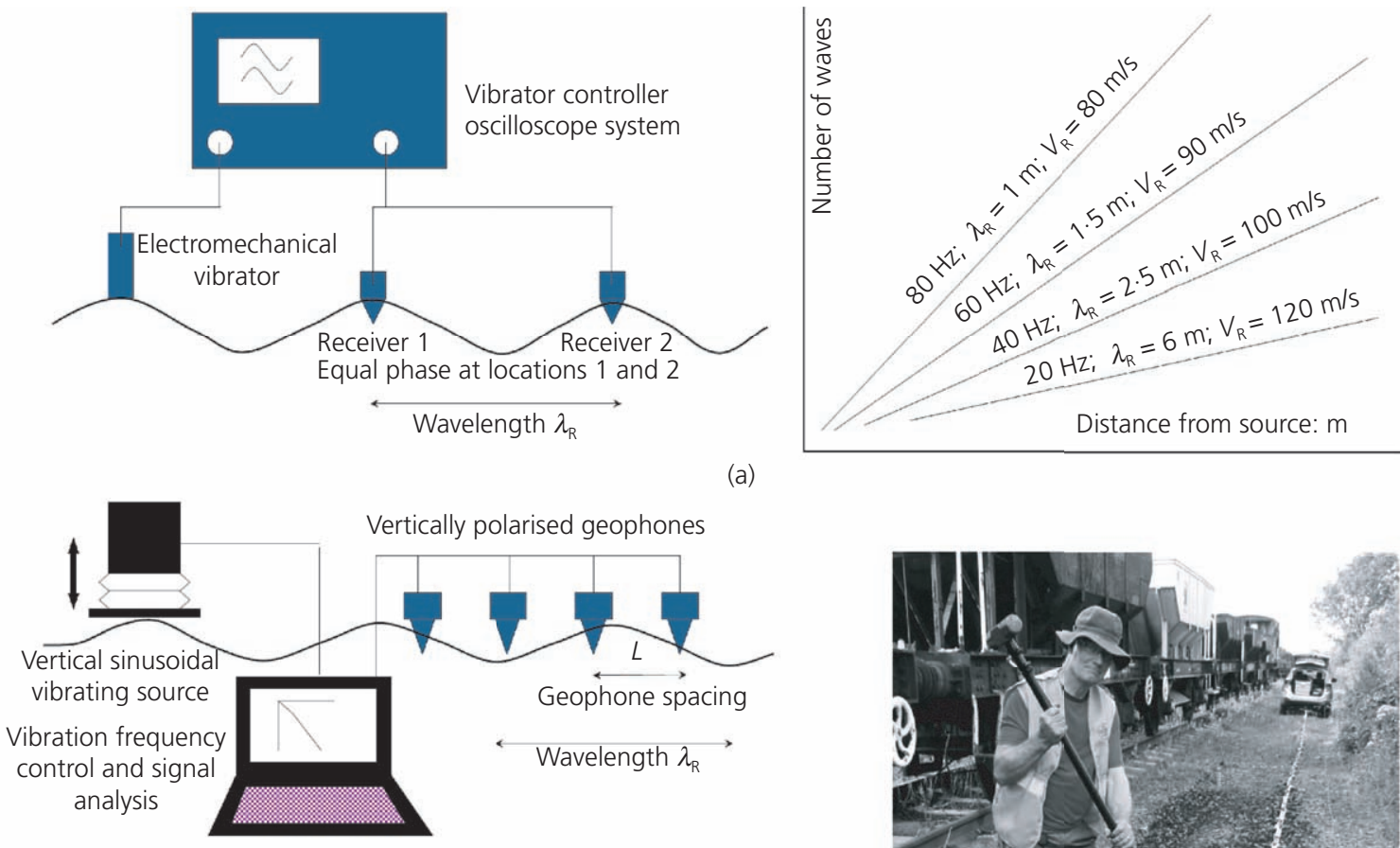

(b)

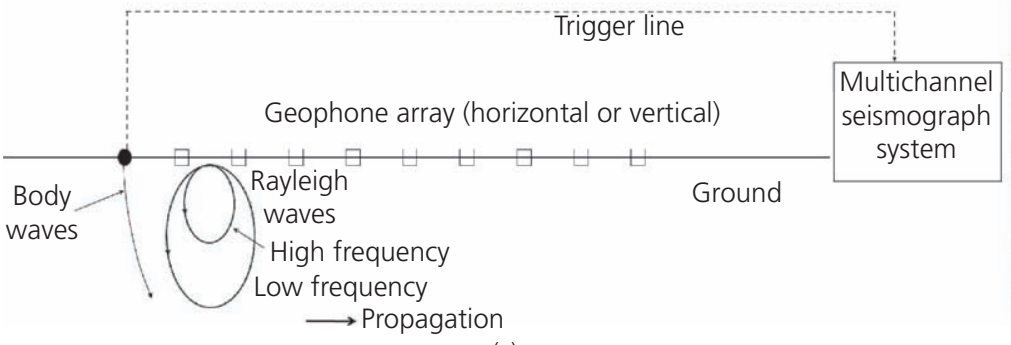

(c)

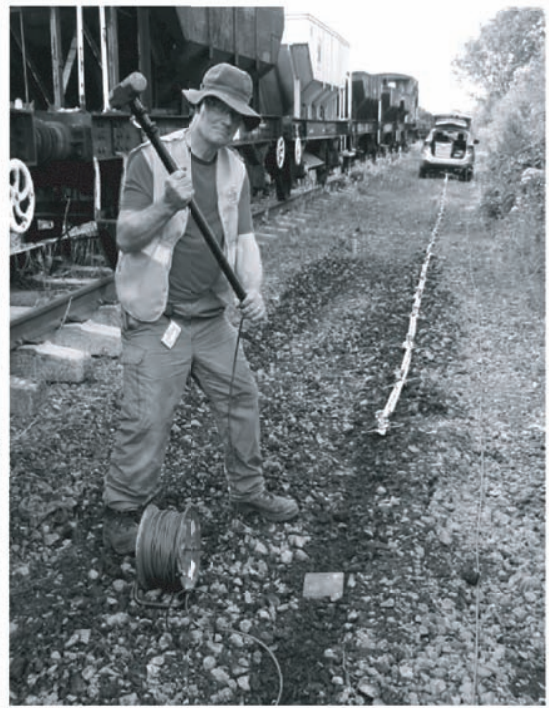

(d)
Figure 2. Field source and receiver configurations used in surface wave surveys. (a) Field curves from two receivers used to calculate phase velocity in the steady-state Rayleigh method (modified from Rix (1988)). (b) Velocity from phase measurements at fixed frequencies on small number of receivers in the CSW method. (c) Velocities across geophone arrays over a range of frequencies calculated in the MASW method. (d) Hammer and plate source and towed streamer use for MASW surveys
Joh (1996) suggested wavelengths as short as one-third of the shortest receiver spacing and as long as three times the largest receiver spacing could be measured with CSW. The range of wavelengths propagated $\left(V_{\mathrm{R}} / f\right.$ from Equation 3$)$ is anticipated for many sites to be from $0.38 \mathrm{~m}$ (minimum velocity of $75 \mathrm{~m} / \mathrm{s}$ at maximum frequency of $200 \mathrm{~Hz}$ ) to $60 \mathrm{~m}$ (maximum velocity of $300 \mathrm{~m} / \mathrm{s}$ at minimum frequency of $5 \mathrm{~Hz}$ ).

MASW can be performed on the data gathered using the same receiver array configuration adopted in shallow seismic refraction and reflection surveying (Park et al., 1999) (Figure 2(c)). This study's MASW surveys employed impulsive sources capable of providing a broad range of frequencies. The source energy was provided by hammer and plate, where higher-frequency ranges are produced by lighter sources. Again, velocity dispersion curves are extracted from the phase delays of the different frequency components of the source signal recorded by the receiver array (Park et al., 1999; Rucker, 2003). MASW surveys were undertaken along profiles running parallel to the axis of embankments. Where static arrays were used, they comprised 24-48 vertically polarised geophones, spaced at 0.5 or $1 \mathrm{~m}$. Longer section coverage was achieved by pulling along and relocating each successive geophone array to overlap with the previous array that was recorded. Where land streamers were used (Figure 2(d)), these comprised a 24channel array of vertically polarised geophones that were mounted on small steel plates, which were towed between intervals equivalent to the shot spacing.

\subsection{Shear wave velocity and stiffness profiles and sections}

In both the MASW and CSW methods, the field dispersion curves were inverted to produce a velocity-depth profile for the shallow 
subsurface (Foti, 2003; Joh, 1996). The profile was referenced to the centre of the geophone array subgroup, whose records are used to construct the dispersion curve, which could include around four geophones for CSW and from around 8 to 12 or even 24 geophones for MASW (Figures 3(a) and 3(b)). The dispersion curve was interactively forward modelled, which involves ground model inversion and generation of an associated modelled dispersion curve with the best fit to the field curve to determine the subsurface shear wave velocity profile (Foti, 2003; Joh, 1996; Raines et al., 2011). The simplest method is attribution of a factored shear wave velocity (usually $1 \cdot 1$ times Rayleigh wave velocity) to a depth equivalent to a fraction of the Rayleigh wavelength $\lambda_{\mathrm{R}}$ (Foti, 2003; Joh, 1996) (Figures 3(c) and 3(d)). A factor of $\lambda_{R} / 3$ is most commonly used because a significant proportion of the particle motion in the ground associated with Rayleigh wave propagation is approximately at this depth (Gunn et al., 2006; Joh, 1996; Richart et al., 1970). The small strain stiffness is the product of the square of the shear wave velocity and the bulk density. The mean (and standard deviation) of 19 bulk density determinations on core from depths of 0.8 to $5 \cdot 2 \mathrm{~m}$ within the embankment fill were $2 \cdot 01 \mathrm{Mg} / \mathrm{m}^{3}\left(0 \cdot 33 \mathrm{Mg} / \mathrm{m}^{3}\right)$ (Gunn et al., 2011), whereas velocity variation ranged from approximately 150 to $250 \mathrm{~m} / \mathrm{s}$, over a $60 \%$ variation. Because the stiffness is sensitive to the square of velocity, the bulk density at all depths can be represented by $2 \cdot 0 \mathrm{Mg} / \mathrm{m}^{3}$, with little effect on the stiffness distribution. On this basis, the stiffness-depth profile

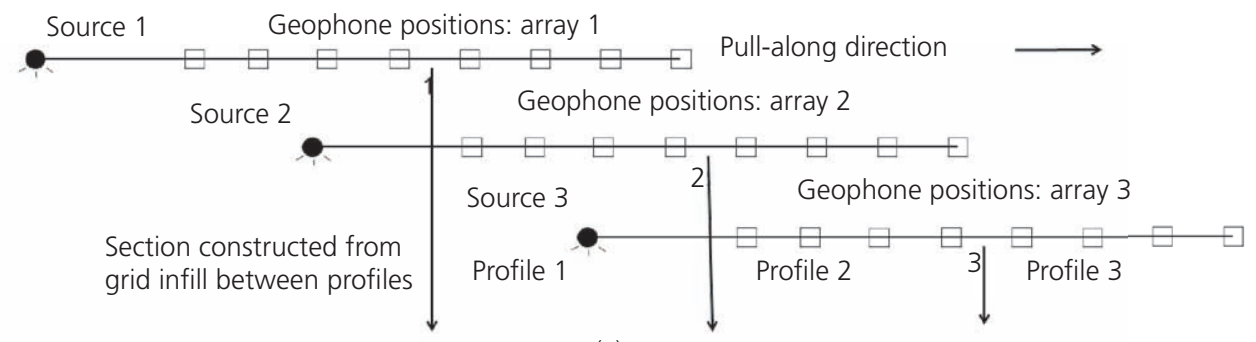

(a)
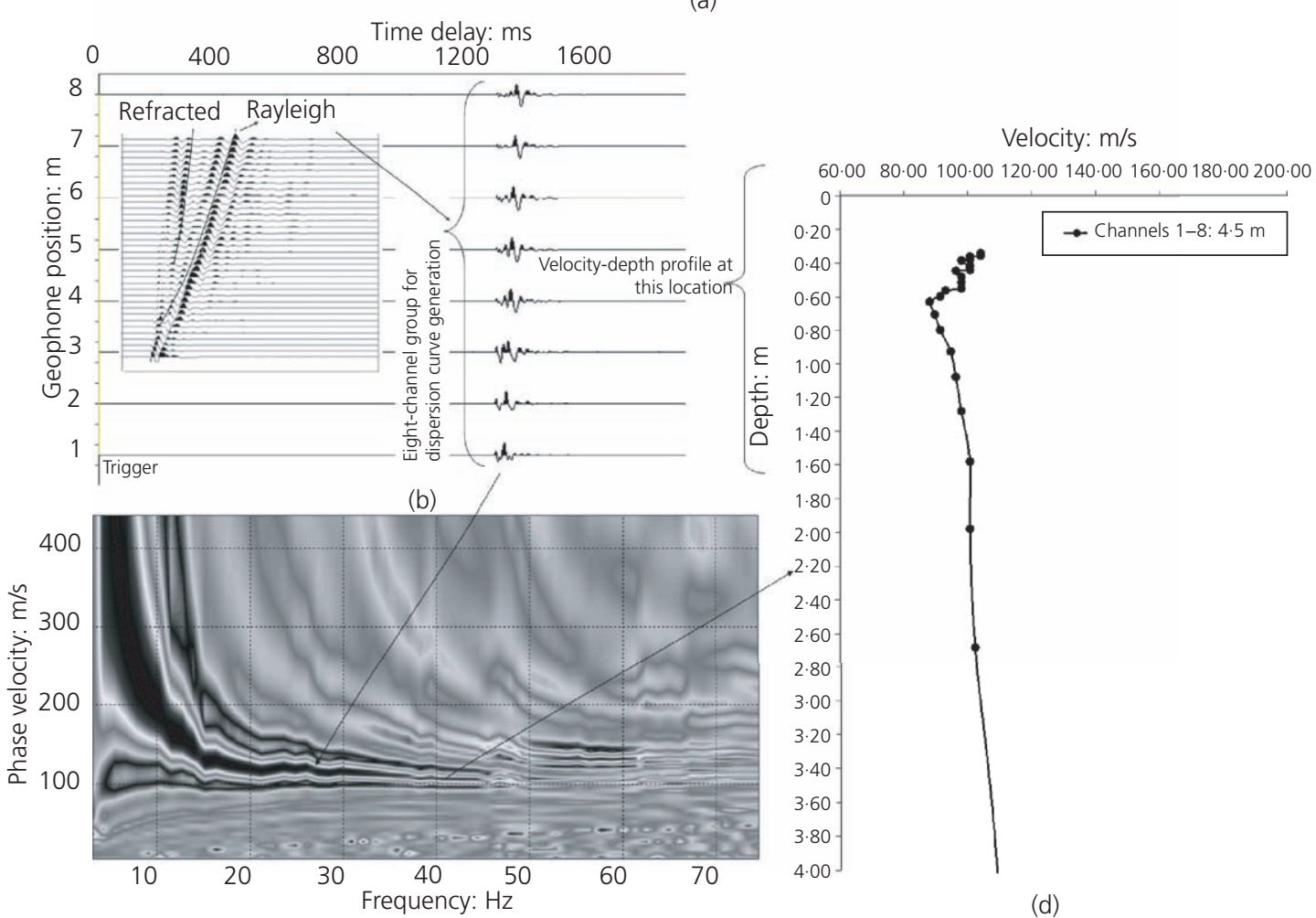

(c)

(d)

Figure 3. Overview of surface wave processing scheme from field coverage to the generation ground model images. (a) Relative positions of one-dimensional profiles by way of roll-along or towed procedures used to generate 2D sections. (b) Field record showing refracted and Rayleigh wave: eight-channel group selected from Rayleigh wave used to construct dispersion curve and velocity profile. (c) Phase velocity-frequency transform for the eight-channel group: Rayleigh wave picked from high-intensity low-velocity feature. (d) Factored S-wave phase velocity-depth profile plotted at group midpoint: depth equivalent to one-third wavelength 
was estimated from the shear wave velocity-depth profile. Twodimensional sections were constructed by contour infilling using anisotropic inverse distance weighting over a grid between each of the shear wave velocity-depth profiles (Gunn et al., 2011, 2013). Also, where MASW surveys were undertaken along a series of parallel arrays, the same weighting method was used to infill grids between the parallel sections to produce a pseudo-3D model of the embankment. (The models were constructed using array parallel surface wave propagation only. More complete 3D models would require surveys across further orthogonally orientated arrays, which are often impractical due to limited crest width across most embankments.)

\section{Case histories}

\subsection{Great Central Railway embankment, East Leake, Nottinghamshire}

CSW and MASW surveys were undertaken along a $140 \mathrm{~m}$ section of an embankment on the Great Central Railway (GCR) that runs south of the overbridge at East Leake, Nottinghamshire, to the East Leake tunnel that passes under the A6006. The whole embankment extends $800 \mathrm{~m}$ and was constructed in 1897 by using end-tipped materials excavated from adjacent cuttings to the south-west (SW) and the north-east (NE) (Bidder, 1900). The railway is operated as a branch from the main line, taking heavy freight class 66 locomotives pulling wagons loaded with supplies for the British Gypsum works at East Leake. Track geometry is very poor due to dipping points and pronounced lateral and vertical warping. Figure 4(a) shows the layout CSW survey stations relative to the line of MASW surveys that were undertaken using a series of static arrays with a $1 \mathrm{~m}$ geophone spacing. Stiffness-depth $\operatorname{logs}$ were generated at a series of locations using both methods, and a ground model was created by way of grid infill between each depth $\log$ (Figure 4(b)).

Interpretation of the 2D section through the embankment (Figure 4(b)) includes a basal, high-stiffness zone below $5 \mathrm{~m}$ depth associated with the underlying Branscombe Mudstone

Sleeper number and position relative

120 to geophys survey grid

- Location of CSW survey

$\because$ Line of MASW survey

Embankment crest within light grey boundary

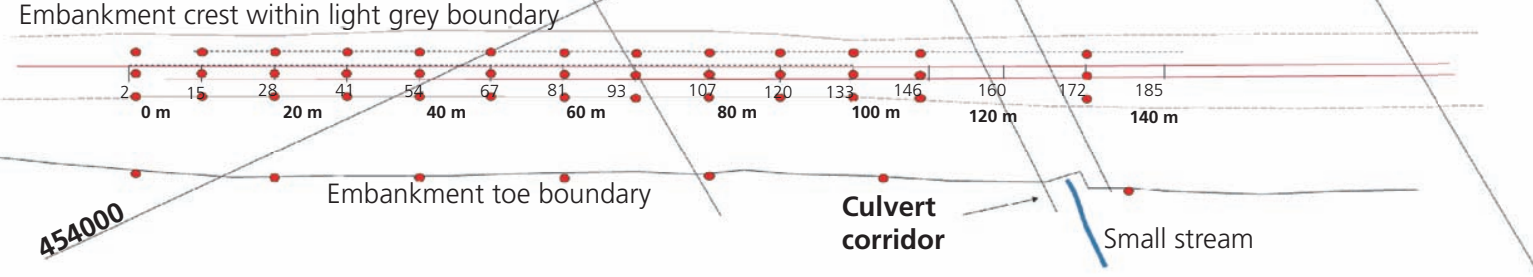

(a)

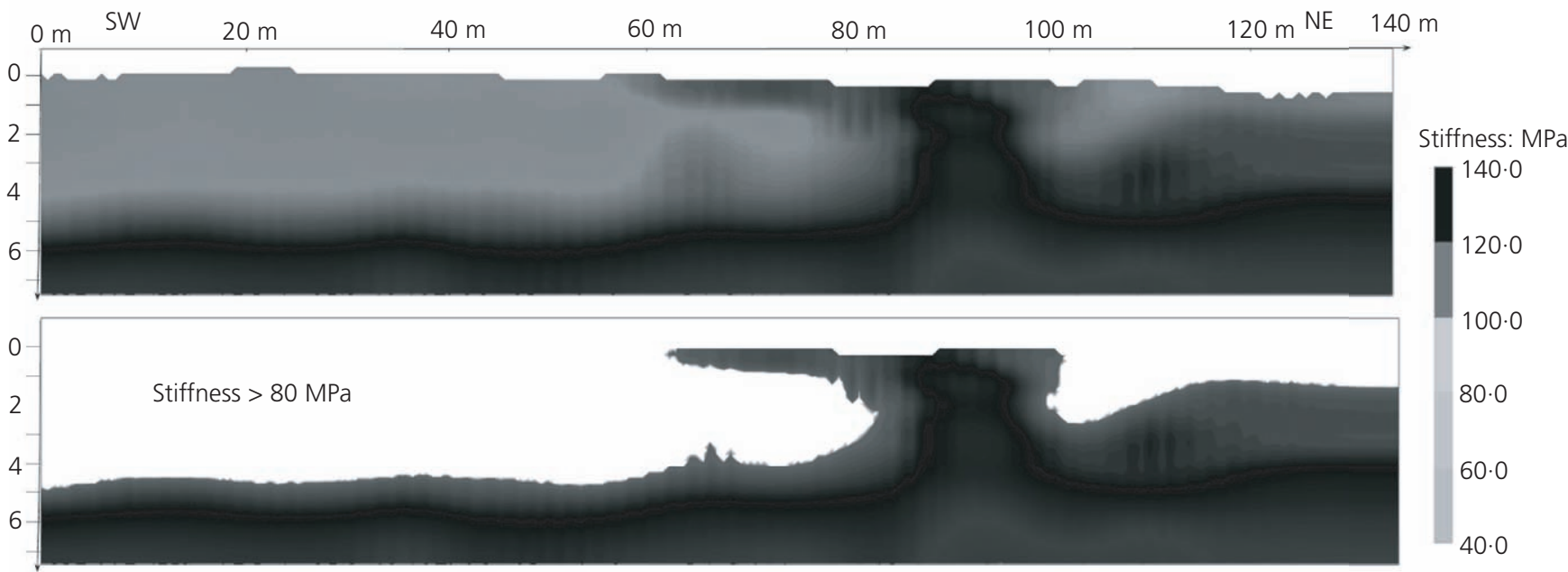

(b)

Figure 4. Ground model constructed from CSW and MASW surveys at embankment along GCR. (a) Field map of embankment showing location of MASW survey lines and CSW profile points (coordinates in bold). (b) Stiffness section showing interface between fine and coarse fill grades 
Formation bedrock and an extensive low stiffness zone in the upper $5 \mathrm{~m}$ interval associated with the engineered fill of the embankment. Within this upper zone, a prominent high-stiffness feature appears between chainage $60-100 \mathrm{~m}$. While in the shallow subsurface between 60 and $80 \mathrm{~m}$, this feature is related to the ballast; from 80 to $100 \mathrm{~m}$, it is associated with a deeper lens extending to the top of the Branscombe bedrock. This lens appears to be associated with infillings of high-stiffness materials, including locally sourced sand, gravel and siltstone. Visualisation of the morphology of the high-stiffness feature across the embankment in three dimensions enables a fuller understanding of the spatial context of the structure in relation to the end-tipping construction technique (Figure 5). Core samples from boreholes through the embankment proved fill source material from local cuttings immediately $\mathrm{SW}$ and $\mathrm{NE}$ of the embankment. Fill materials to the SW of the small stream include Westbury Mudstone that has degraded to soft clay, siltstone of the Blue Anchor Formation (also degraded to clay in places) from the cutting to the SW and glaciofluvial sand and gravel, thought to be a later infill from local quarries (Bidder, 1900). Clays from the Westbury Formation have stiffnesses ranging from 40 to $80 \mathrm{MPa}$, whereas the Blue Anchor siltstone and the glaciofluvial sands and gravels tend to be associated with stiffnesses greater than $80 \mathrm{MPa}$ (Gunn et al., 2013). Figure 5(b) shows stiffnesses from 80 to $120 \mathrm{MPa}$ - that is, effectively removing the clays of the Westbury Mudstone and also revealing the original ground surface on which the embankment was tipped. Limiting the stiffness ranges enables a domain or anatomical visualisation of morphology, such as the high-stiffness structure (from 60 to $100 \mathrm{~m}$ ) dominated by Blue Anchor siltstone and glaciofluvial sand and gravel fill. The authors believe that this feature resulted from end tipping as larger boulders ran downslope to the toe of the advancing embankment to be later infilled by finer materials. The engineer in charge of works, Bidder (1900), did not explicitly describe the East Leake embankment construction, but photographs by S. W. A. Newton show end-tipping wagons of the contractor, Henry Lovatt, at the East Leake tunnel cutting, which is consistent with the 'cut-and-fill' methods used at the time (LCC, 2016).

\subsection{Knottingley and Goole canal embankment, Eggborough, North Yorkshire}

The study site was a section of embankment, approximately $450 \mathrm{~m}$ west-north-west of Whitley Bridge near Eggborough, in the Selby district of North Yorkshire. The embankment, constructed in 1821, forms the retaining barrier on the southern side of the canal, which is raised above the surrounding land by approximately $1.75 \mathrm{~m}$. The site is within a section of the embankment, which is lined on the waterside by a vertical masonry wall made of large gritstone ashlars. Parts of the masonry-lined section of the embankment have shown a history of void formation and leakage, resulting in localised partial collapse of the embankment. A series of surface openings were observed during visual inspections in September 2008. One of the prominent features was a collapsed cavity showing significant water seepage at its base. The surface opening appeared to be approximately oval, $1 \mathrm{~m}$ by $0.7 \mathrm{~m}$. The subsurface cavity appeared to be funnel shaped, decreasing in diameter with depth, but extending to $1 \mathrm{~m}$ or deeper. It is suspected that the masonry wall was originally lined with puddle clay and the embankment to have been side tipped against the wall. The water appears to have

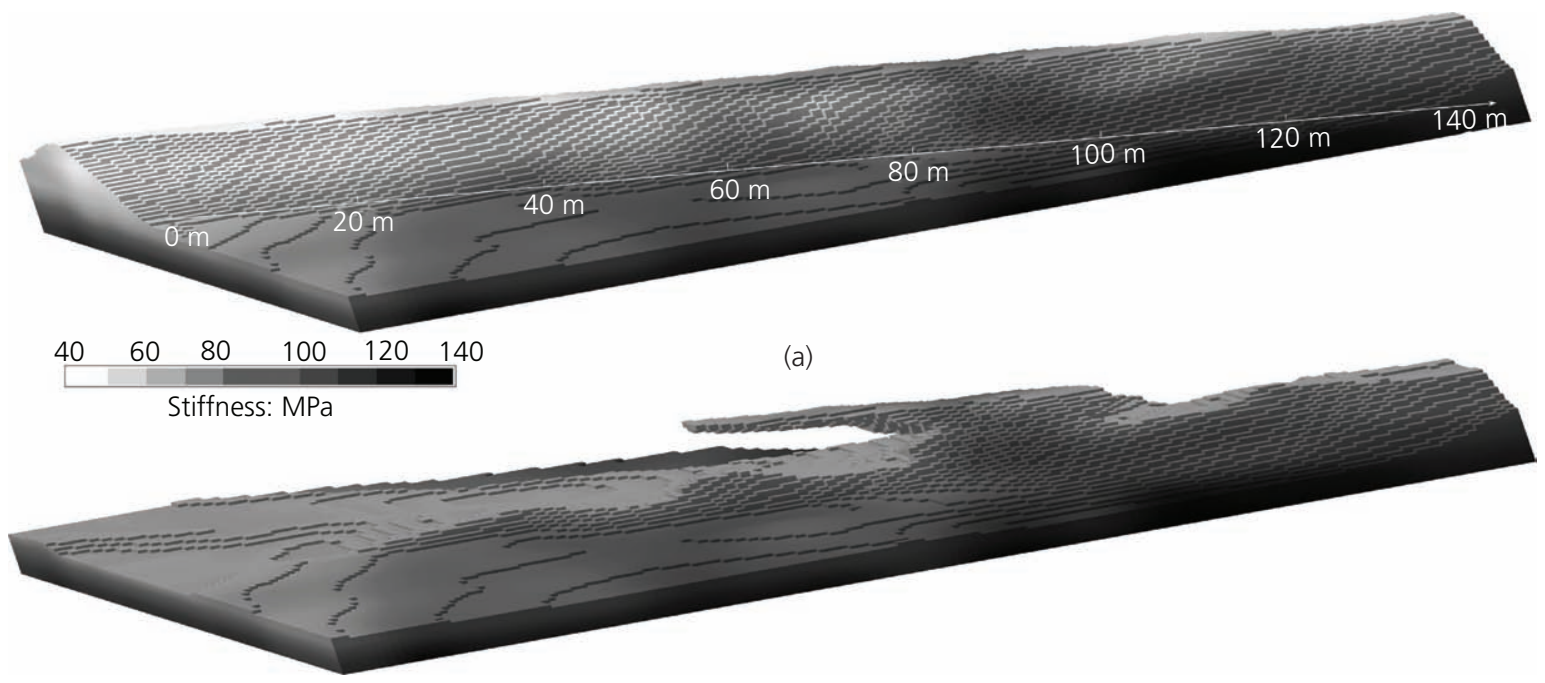

(b)

Figure 5. Anatomical visualisation of embankment end-tip structure by way of deconstruction of a 3D ground stiffness model. (a) Stiffness range: $40 \mathrm{MPa}<$ stiffness < $140 \mathrm{MPa}$.

(b) Stiffness range: $80 \mathrm{MPa}<$ stiffness $<140 \mathrm{MPa}$ 
breached the puddle clay seal, entered the north side of the cavity at a depth of around $0.75 \mathrm{~m}$ and to have flowed in a southwesterly direction deeper into the embankment.

A complete MASW survey was undertaken along four transects, each running parallel to the line of the canal, but offset from the masonry wall by $2-4 \mathrm{~m}$; see Figure 6 . Each line was $17.5 \mathrm{~m}$ long, comprising 36 channels of vertically polarised geophones spaced at $0.5 \mathrm{~m}$. Embankment geomorphology and survey lines were positioned within local and British National Grid coordinate grids using a Leica SmartRover Global Positioning System (GPS). GPS points were at $0.5 \mathrm{~m}$ along the axis of the embankment and $1 \mathrm{~m}$ across the flank. Source locations included an end line offset of $4 \mathrm{~m}$, an end line location and locations within the line spaced at $4 \mathrm{~m}$ intervals to enable clearly defined pulses with high signal-noise ratios to be identified on the field traces of the nearby subgroups of geophones. This was done to guard against the loss of high-frequency energy, which is highly attenuated in heterogeneous or disturbed ground.

A 3D ground model was constructed by way of weighted infill of a grid between each of the shear wave velocity profiles created along a series of overlapping eight-channel geophone groups

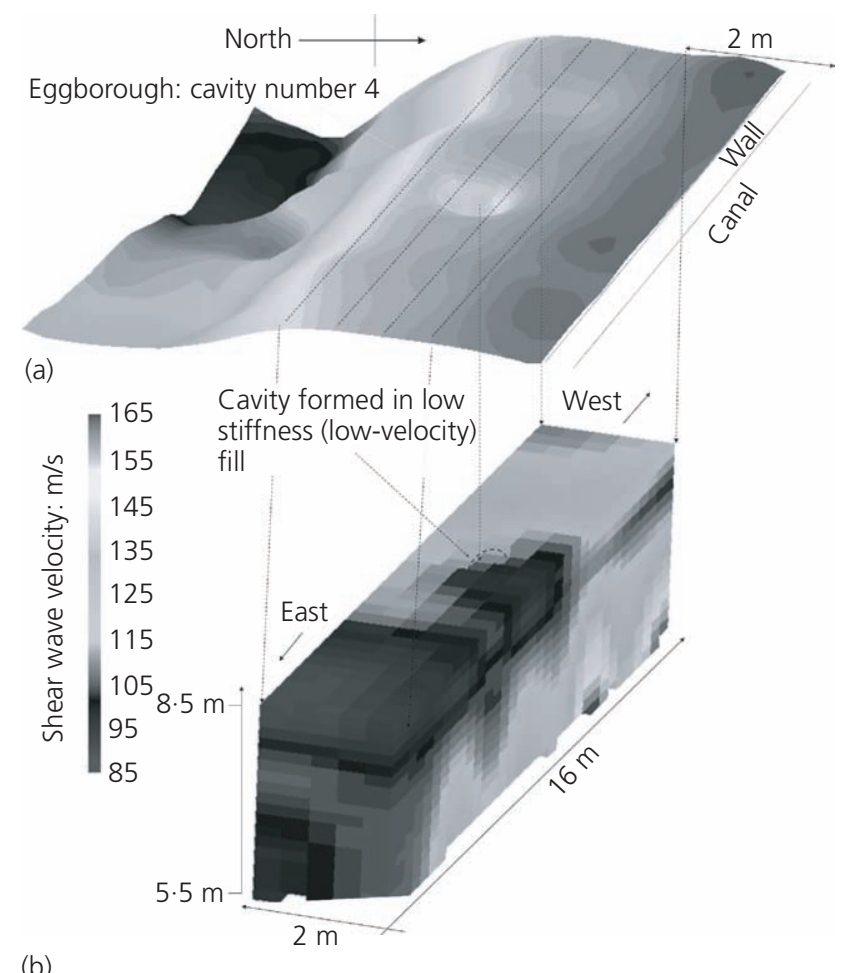

(b)

Figure 6. Surface wave surveys at embankment along Knottingley and Goole canal near Eggborough. (a) Location of the model section relative to cavity, embankment axis and positions of geophone line arrays. (b) Subsurface structure visualised by way of 3D shear wave velocity model along each survey line (Figure 6). The aerial extent of the model extends $16 \mathrm{~m}$ along the axis and $2 \mathrm{~m}$ across the transect of the embankment, approximately centred on the surface void; the depth interval is from 0.5 to $3 \mathrm{~m}$ below the embankment crest. The model includes velocities in the range of $85-165 \mathrm{~m} / \mathrm{s}$. The broad characteristics of soils associated with velocities in the range of $85-100 \mathrm{~m} / \mathrm{s}$ can be considered as loose (low packing density) coarse-grained or poorly compacted, very soft or soft fine-grained soils (possibly of strengths $<40 \mathrm{kPa}$ ) (Gunn et al., 2003; Hardin and Richart, 1963; Richart et al., 1970). In contrast, the broad characteristics of soils associated with velocities in the range of $140-165 \mathrm{~m} / \mathrm{s}$ can be considered as medium-dense, coarse-grained or firm, fine-grained soils (possibly of strengths $>75 \mathrm{kPa}$ ). Thus, the contours within this soil classification indicate an overall wedge of lower-velocity, more poorly compacted, lower-strength material thickening towards the east (lower $x$-axis values) - shown as the darker zones in Figure 6. Within this wedge, two near-surface very low-velocity $(85-90 \mathrm{~m} / \mathrm{s})$ zones occur, where one coincides with the open cavity. A highervelocity $(>130 \mathrm{~m} / \mathrm{s})$, higher-strength, stiff basal zone occurs deeper into the section, which the authors suspect would coincide with the base of the embankment or the top of the underlying superficial geology.

The boundary between the stiffer base (i.e. shear wave velocity $>130 \mathrm{~m} / \mathrm{s}$ ) and the overlying weaker soils undulates with a series of marked peaks and troughs, which the authors suspect provide a subsurface channel for groundwater escaping from the canal to drain into the embankment and formation. Progressively removing ground with velocities below $120 \mathrm{~m} / \mathrm{s}$ from the $3 \mathrm{D}$ model reveals a trough that appears spatially coincident with the flow of water into a subsurface pipe observed from a view into the void (Figure 7). (This observation was made from a position equivalent to $x=8 \mathrm{~m}, y=1 \mathrm{~m}$ on the local survey grid.) The authors suspect that this trough is formed in stiff sandy, silty clay, where overlying, looser, less cohesive materials were removed by water flowing into this zone by way of a breach in the canal wall and puddle clay seal. At site, water was observed in video recordings to enter the subsurface pipe from the north, at approximately $0.75 \mathrm{~m}$ deep and at $x \cong 8.5 \mathrm{~m}$ along the section. The authors suspect that the wall and embankment were breached further to the east and that the water followed within the low-velocity interval $(<90 \mathrm{~m} / \mathrm{s})$ between 0.5 and $1 \mathrm{~m}$ deep and between $x=7 \mathrm{~m}$ and $x=8 \mathrm{~m}$ seen in sections $y=0-0 \cdot 5 \mathrm{~m}$ in Figure 7 .

\subsection{Laverton railway embankment, Worcestershire}

The Laverton embankment marks the point of a halt in the trains on the current heritage Gloucester and Warwickshire railway. The line was originally part of the Great Western Railway's Cheltenham-Stratford-upon-Avon-Birmingham line, known as the Honeybourne line, built between 1900 and 1906. The Laverton embankment is around $6 \mathrm{~m}$ high and is believed to have been constructed by way of end tipping of local Charmouth Mudstone. Currently, the embankment comprises a $0.9 \mathrm{~m}$ thick upper layer of ballast fouled with fines, ash and soil (rich in humus), generally 


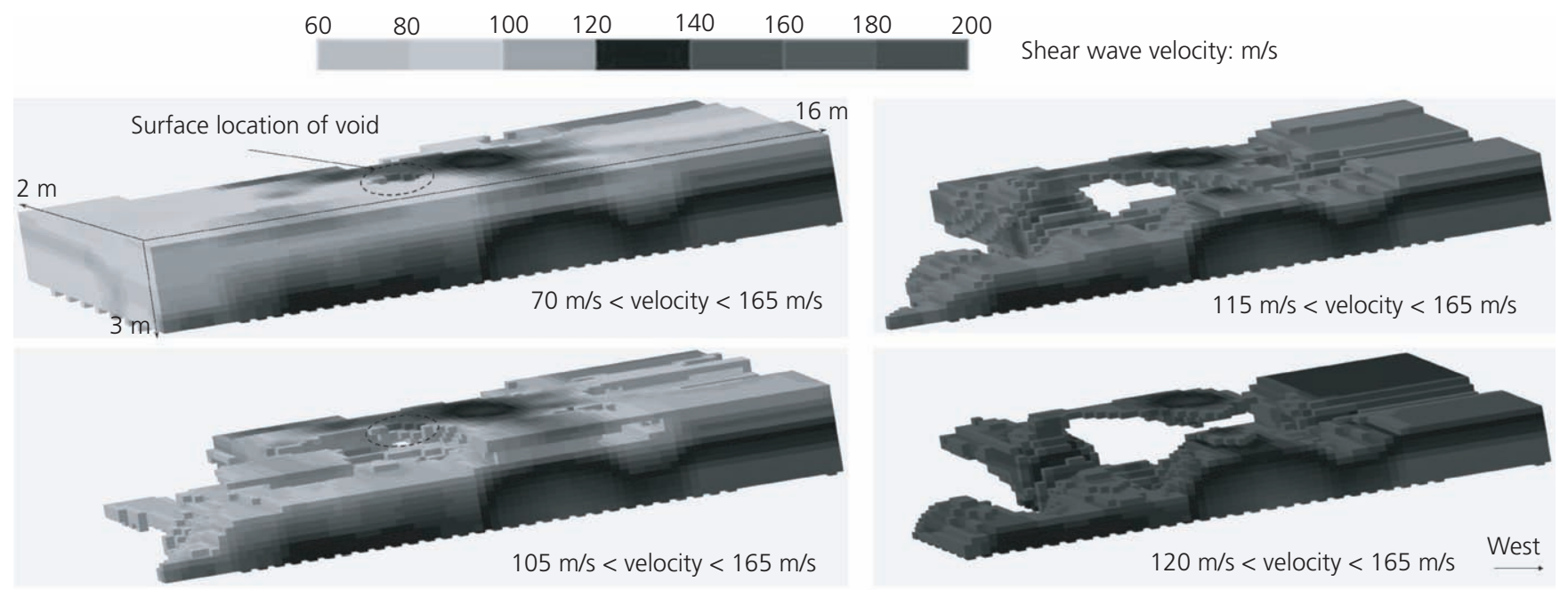

(a)

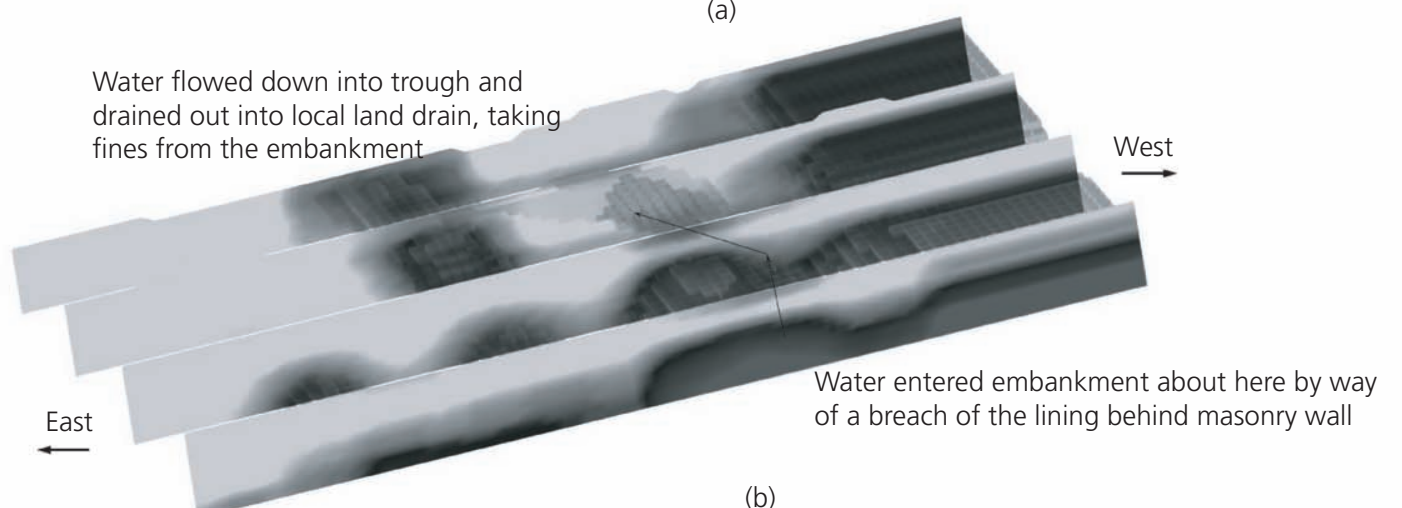

(b)

Figure 7. Void associated with very low velocity zones in 3D ground shear wave velocity model. (a) Extent of void highlighted using selected iso-volume velocity ranges. (b) Fence panels show small trough structure through which water flowed from canal into void underlain by clay fill of reworked Charmouth Mudstone of about $5 \mathrm{~m}$ high. The pits at CPT 3 and CPT 4 (see Figure 8) revealed a layer of cobbles (usually of 100-250 mm dimensions) at the base of the ballast that would have been laid as part of the original engineered subgrade, as shown in Figure 9. Figure 8(a) shows the location of repeat MASW surveys that were undertaken at 2-month intervals by using a 24-channel land streamer with $4 \cdot 5-\mathrm{Hz}$ geophones spaced at $1 \mathrm{~m}$. Each time, a $300 \mathrm{~m}$ long survey line was completed as a series of 50 increments each $6 \mathrm{~m}$, where in each case Rayleigh waves were generated by a hammer/plate source offset $2 \mathrm{~m}$ from the nearest geophone (Figure 2(d)). A dispersion curve was generated for each source-line location, and an associated shear wave velocity profile plotted at the midpoint of the 24-geophone array. A 2D section was generated from each survey by infilling a grid between each velocity profile (Figure 8(b)).

The south-south-west (SSW) half of the section of the embankment may have been constructed in two lifts, possibly with the boundary at about $3 \mathrm{~m}$ depth. Generally, the upper interval exhibits very low penetration resistances of around $1 \mathrm{MPa}$, while the fill between 3 and $5 \mathrm{~m}$ exhibits slight greater penetration resistances $(1 \cdot 3 \mathrm{MPa})$. Sampling of the clay immediately beneath the ballast around CPT 3 indicated high levels of moisture and weathering. Overall, the corresponding shear wave velocity ranges in the SSW half (0 to CPT 6 at station $180 \mathrm{~m}$ ) of the section are $80-90 \mathrm{~m} / \mathrm{s}$ around $1 \mathrm{~m}$ depths; $100-120 \mathrm{~m} / \mathrm{s}$ around $1.5 \mathrm{~m}$ depths; $140-150 \mathrm{~m} / \mathrm{s}$ around $3 \mathrm{~m}$ depths; and up to $180 \mathrm{~m} / \mathrm{s}$ around $5 \mathrm{~m}$ depths. The shear wave velocity section indicates an apparent stiffening of the mid and basal zones of the north-north-east (NNE) half of the embankment. The CPT 9 log indicates a thinning of the low penetration resistance interval beneath $1 \mathrm{~m}$ interval of ballast for example to around $0.5 \mathrm{~m}$ thick. Beneath this, penetration resistances within the interval from 1.5 to $4 \mathrm{~m}$ are above $2 \mathrm{MPa}$, where the associated shear wave velocities are around $140-160 \mathrm{~m} / \mathrm{s}$. This change in the geotechnical properties may relate to increased trafficking or use of different materials in the NNE half of the section approaching the drainage culvert.

Figure 10(a) shows a section of the cone penetration resistance $q_{\mathrm{c}}$ across the embankment located close to the location of CPT 3 in Figure 8 (a). The embankment and the weathered zone of the 


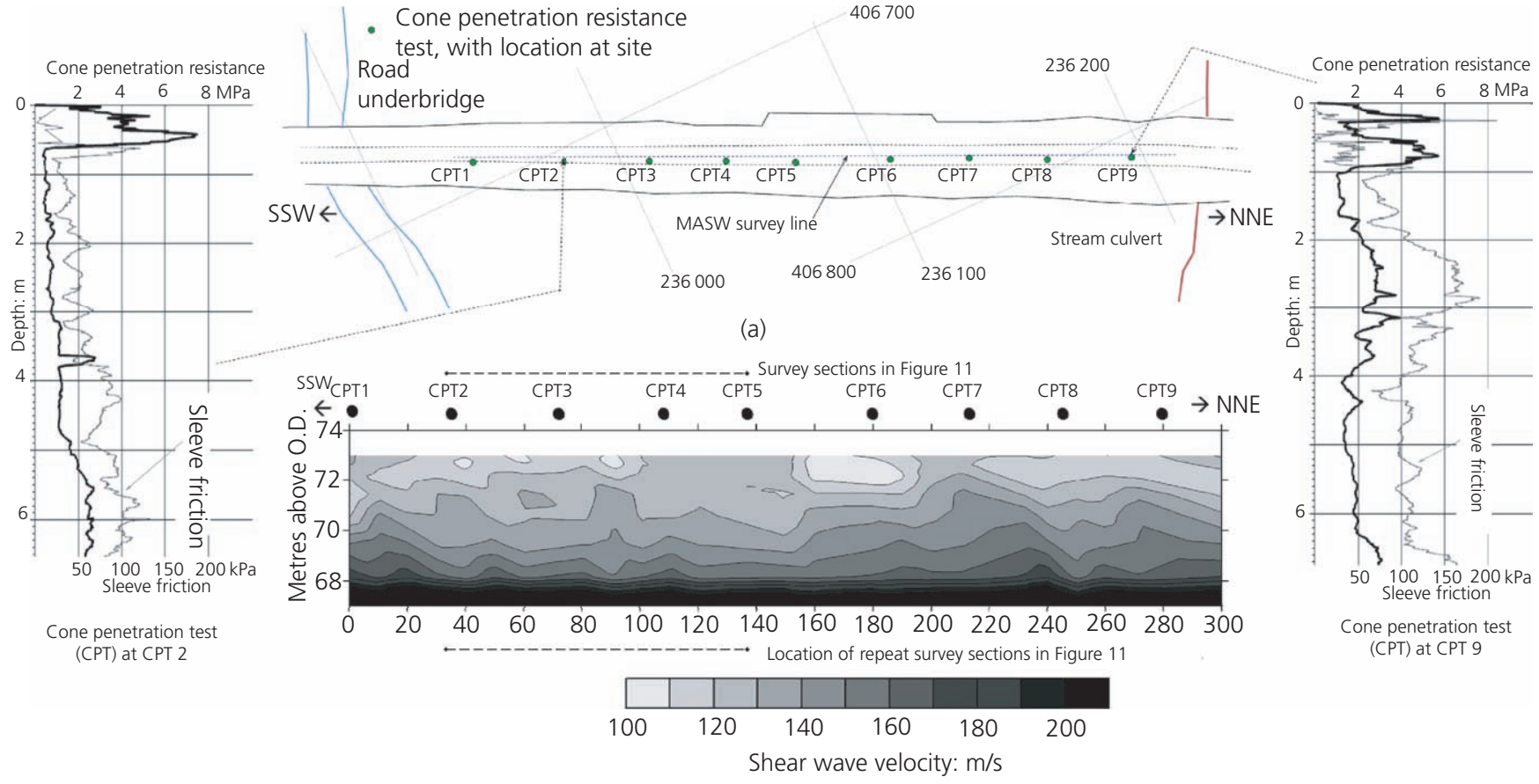

(b)

Figure 8. MASW survey at the Laverton embankment along the Gloucestershire-Warwickshire railway. (a) Layout of survey line relative to CPT profile locations. (b) 2D section of shear wave velocity profile along the axis of embankment

underlying formation can readily be distinguished from the unweathered formation. Values up to $1 \mathrm{MPa}$ are present in the upper interval to around $2.5 \mathrm{~m}$ deep below the crest and in the upper $1 \mathrm{~m}$ over the east flank. Values within the lower interval (3-5 m) of the embankment range from 1 to $2 \mathrm{MPa}$. Values in the formation increase from around $2 \mathrm{MPa}$ in the upper $1 \mathrm{~m}$ of the weathered material to above $4 \mathrm{MPa}$ in the unweathered Charmouth. Core logs from a borehole at CPT 3 indicate relatively high moisture content levels and low densities throughout the embankment fill (Figure 10(b)). The density log shows a slight increase in density with depth with a mean bulk density through the embankment of $1.92 \mathrm{Mg} / \mathrm{m}^{3}$, which is below

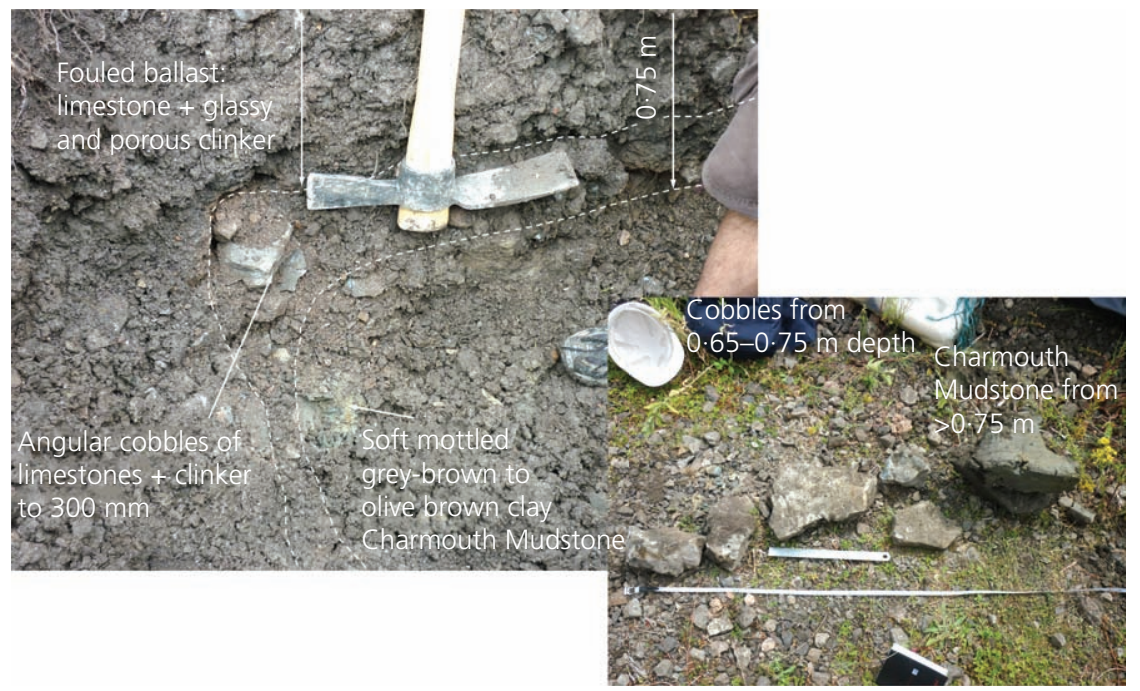

Figure 9. Photograph of wall and floor of pit at CPT 3 


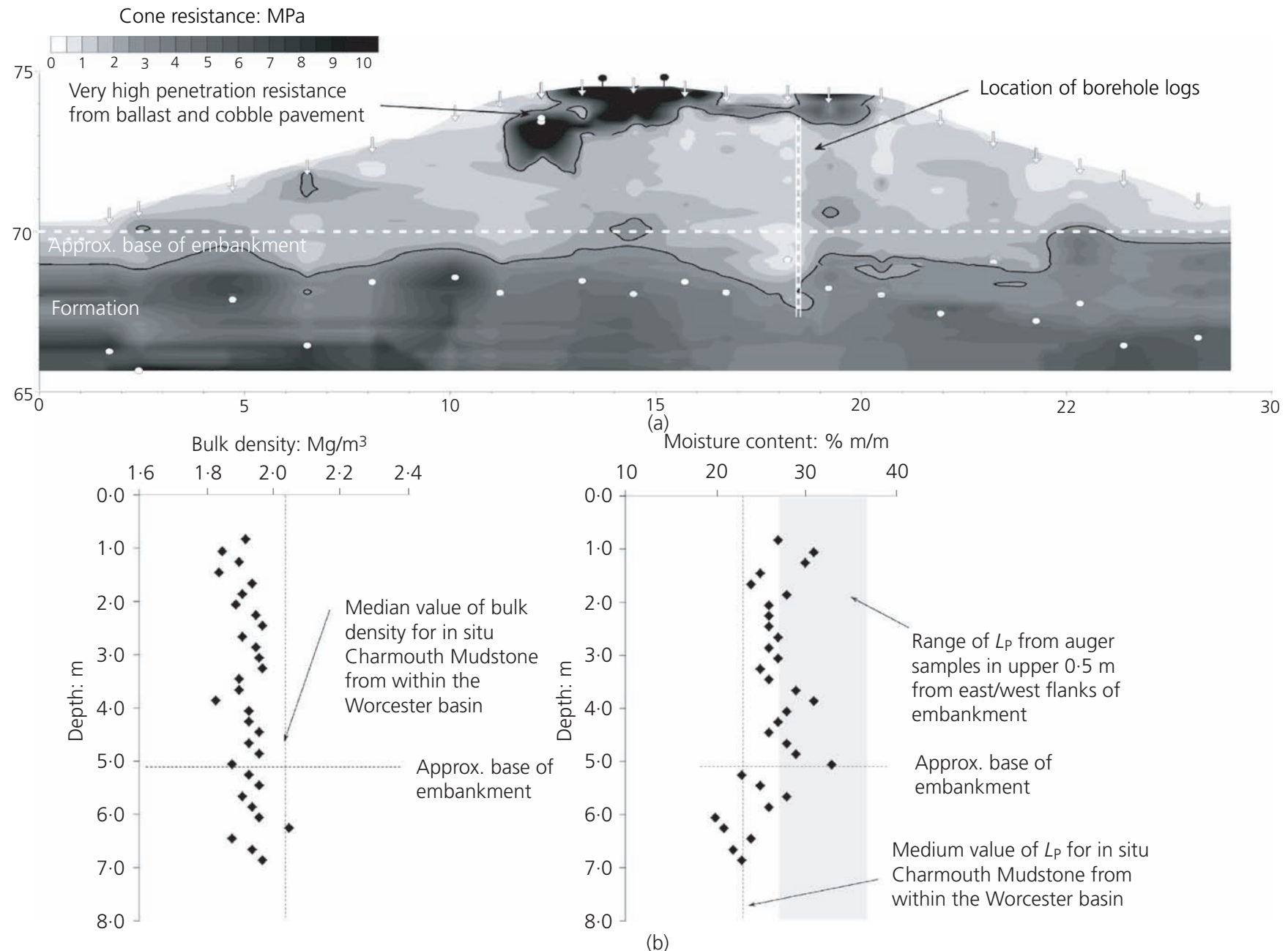

Figure 10. Geotechnical properties through Laverton embankment section near CPT 3. (a) 2D cross-section showing CPT penetration resistance. (b) Moisture content and bulk density profiles from core taken beneath embankment crest

the median value for bulk density of samples gathered from in situ outcrops in the Worcester basin reported by Hobbs et al. (2012) (see Table 1). Relatively low densities are consistent with fill of reworked material - for example a consequence of the cutfill construction method and subsequent ageing processes such as shrink-swell and fissure development associated with seasonal moisture cycling. Testing on unweathered in situ Charmouth Mudstone sampled from outcrops in the Worcester basin around Laverton by Hobbs et al. (2012) provided values for drained cohesion $c^{\prime}$ and friction angle $\phi^{\prime}$ of $19 \mathrm{kPa}$ and $26^{\circ}$; see Table 1 . Equivalent test values on recompacted auger samples recovered from shallow depths were $11 \cdot 3 \mathrm{kPa}$ and $19 \cdot 3^{\circ}$ from the east flank, where values of $7 \cdot 3 \mathrm{kPa}$ and $16 \cdot 2^{\circ}$ from the west flank appear to be very close to residual. Thus, it is likely that fill close to residual strength occurs within a shallow interval (upper $0 \cdot 5-1 \mathrm{~m}$ ) across the flanks and also the upper interval just underlying ash beneath the rails. Atterberg index tests on the fill materials augered from the upper $0.5 \mathrm{~m}$ on the east and west flanks indicated plastic $\left(L_{\mathrm{P}}\right)$ and liquid $\left(L_{\mathrm{L}}\right)$ limits within the ranges of 27-37 and 61-77\%. Moisture levels over several intervals through the fill are within this $L_{\mathrm{P}}$ range, which is considerably greater than the natural in situ $L_{\mathrm{P}}$ of $23 \%$ (Figure 10(b)). Because of its high moisture state, the fill consistency here is low. It is likely to be low throughout the zones of low shear wave velocity from CPT 1 to CPT 5 and also around CPT 6, showing how the surface wave image can potentially identify parts of the embankment that are more susceptible to plastic deformation and, potentially, shear failure. Around CPT 3, morphological features including a midslope berm with lower slope bulging provide evidence of progressive deformation. Backscarp, accumulation and run-out zones from a former slip occur above a widened embankment between CPT 5 and 6, which is either the original slipped material or added toe support. Combined moisture content logging and repeat MASW surveys by Bergamo et al. (2016) 
Reworked Charmouth Mudstone from embankment samples (6 number off)

\begin{tabular}{lll}
\hline Mean bulk density: $1.92 \mathrm{Mg} / \mathrm{m}^{3}$ & Plastic limit range & Liquid limit range \\
Moisture content: range: $23-33 \%$ & $27-37 \%$ & $61-77 \%$ \\
$\begin{array}{l}\text { Mean: } 26 \% \\
\text { Triaxial tests at effective stress }\end{array}$ & Drained cohesion $\mathrm{C}^{\prime}: \mathrm{kPa}$ & Drained friction angle $\phi^{\prime}:$ 。 \\
East flank (upper $0.5 \mathrm{~m}$ ) & 11.3 & $19 \cdot 3$ \\
West flank (upper $0.5 \mathrm{~m}$ ) & $7 \cdot 3$ & 16.2
\end{tabular}

Median values for Charmouth Mudstone in Worcester basin from Hobbs et al. (2012) (number off samples stated)

Index test values (>100 samples)

Bulk density: $2 \cdot 03 \mathrm{Mg} / \mathrm{m}^{3}$

Natural in situ moisture content: $22 \%$

Triaxial tests at effective stress

(>10 samples)

Residual values

\section{Plastic limit}

$23 \%$

BS EN 1377-1:1990 (BSI, 1990a)
Liquid limit
$53 \%$

BS EN 1377-8:1990 (BSI, 1990b)

Drained cohesion $\mathrm{C}^{\prime}$

$19 \mathrm{kPa}$

Drained cohesion, $C_{r}^{\prime}$

$9 \mathrm{kPa}$
Drained friction angle $\phi^{\prime}$

$26^{\circ}$

Drained friction angle $\phi_{r}^{\prime}$

$14^{\circ}$

Table 1. Geotechnical properties of Charmouth Mudstone measured on samples taken from the Laverton embankment and outcrops within the Worcester basin

showed a dependence of $V_{\mathrm{S}}$ on the moisture content within the embankment core. In Figure 11, the sequence of sections between CPT 2 and CPT 5 captured in 2014 indicate velocity changes respond very dynamically to weather events. The lowest velocities $(<110 \mathrm{~m} / \mathrm{s})$ occur in the upper $3 \mathrm{~m}$ over the SSW half of the section between CPT 2 and CPT 3, where very soft clay fill was observed. While velocities are greater (up to $130 \mathrm{~m} / \mathrm{s}$ ) in the NNE half between CPT 4 and CPT 5, larger velocity changes also occur here. Notable are the surveys on 14 January within a period of heavy rain and 14 September within a relatively dry spell. These sections provide some insight into the possible end-member conditions - for example those that could be potential trigger points to inspect the embankment for evidence of either very wet or very dry fissured near surface fill. Currently, progressive deterioration in shear strength can only be inferred from repeat $V_{\mathrm{S}}$ surveys. However, quantitative condition assessment is a real possibility in the near term provided robust relationships between shear strength, stiffness and shear wave velocity can be established.

\section{Conclusions}

CSW and MASW surface wave surveying provide rapid, portable and non-intrusive tools to assess the small strain stiffness characteristics of the railway subgrade and embankment fill. Information is provided in the form of a stiffness profile that provides a useful input into models to characterise the subgrade response to static and dynamic loads. Survey measurements are repeatable, making these methods very suitable to assess the efficacy of retrospective stiffening of the subgrade such as by vibrotamping, soil nailing or chemical treatment, such as shown in the case histories by Moxhay et al. (2001, 2008). In the case histories presented in this paper, signal frequencies up to $200 \mathrm{~Hz}$ were measureable with the CSW, whereas the MASW was often limited to frequencies below $100 \mathrm{~Hz}$. Signal frequency limitations can occur in the MASW method when using heavier source hammers or long offset distances, but these can be readily overcome by using lighter sources at closer offsets or using high frequencies with a CSW method. Impulsive sources are more convenient and combined with spectral processing yield results far more rapidly than continuous frequency approaches such as used in CSW surveys. Thus, provided a source or sources can be used to generate a relatively wide frequency band (e.g. 5-100 Hz), an MASW survey will provide more effective ground coverage. Simple MASW survey field procedures to guard against 'far offset' effects include the use of a constant source-nearest receiver distance and roll-along receiver array relocation to extend lateral coverage.

Like most non-invasive geophysical imaging methods, MASW arrays can be scaled to capture complex structures within aged geotechnical assets. The case histories demonstrate that heterogeneity of aged earthwork structures is not consistent with uniform, laterally extending horizontal layers. Two-dimensional sections can be built up from a series of inline velocity-depth profiles spaced at intervals suitable for capturing the heterogeneity 

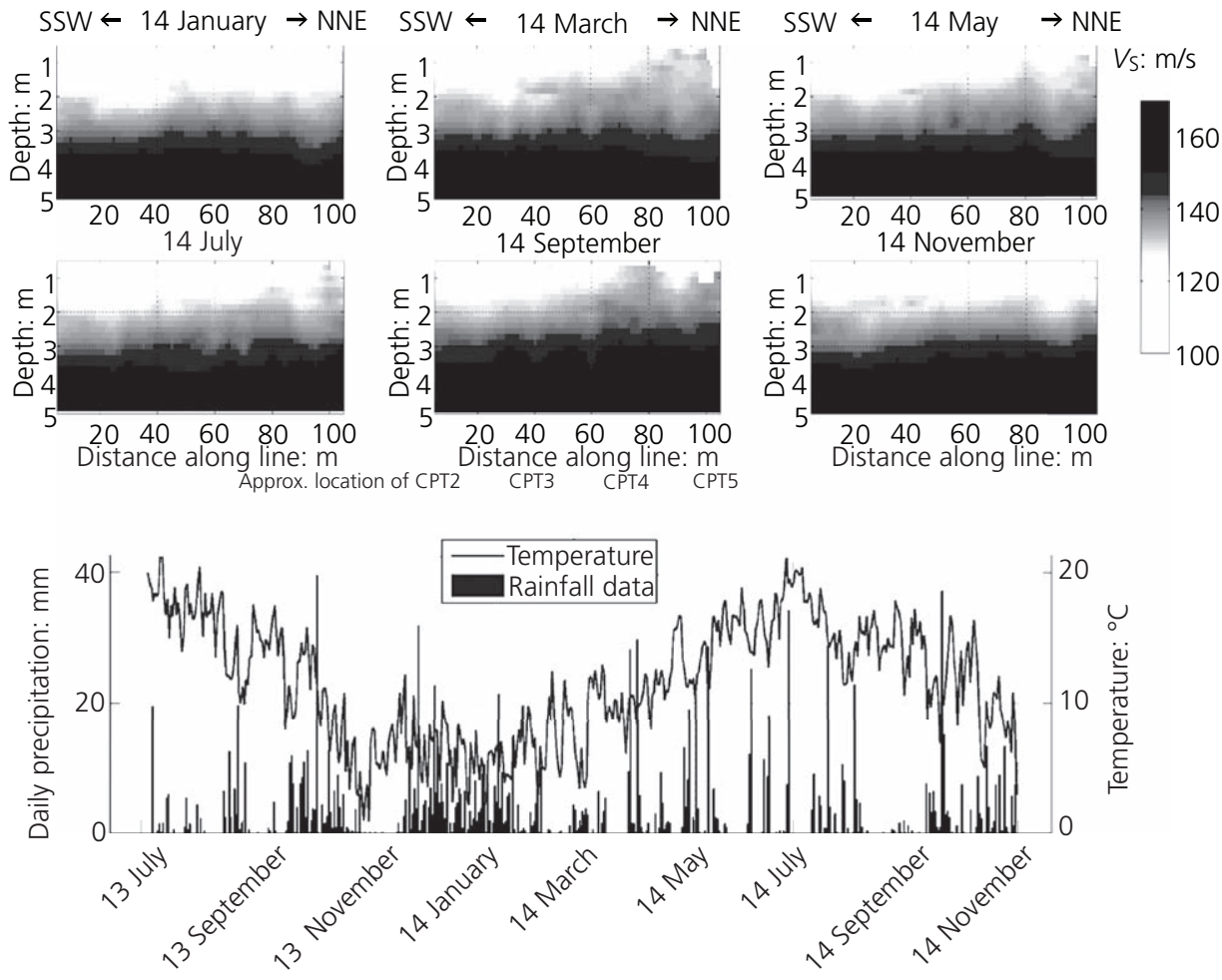

Figure 11. Embankment velocities relative to 2014 temperature and rainfall sequence (after Bergamo et al., 2016)

even on a submetric level. Pseudo-3D sections can be constructed using a series of CSW surveys or using an MASW approach with overlapping gathers of selected channels in subgroups of geophones from larger geophone arrays. Heterogeneous structure related to original construction or the effect on strength-related properties of subsequent localised deterioration within the asset can be located on high-resolution $V_{\mathrm{S}}$ or stiffness images. Anatomical imaging is possible, including the location of stiffness contrasts between different engineering materials, understanding dynamic load performance and early identification of progressive subgrade deterioration that precedes track problems or slope failure.

\section{Practical relevance and potential applications}

Avoidance of the costs associated with service and business disruptions provide compelling cases for early interventions; stated simply by Glendinning et al. (2015) as 'emergency repairs cost 10 times that of planned works'. 'Early' is about when to intervene, or when to act, which depends on the definition of earthworks condition and the subsequent problems and solutions. The metrics used to define condition are very dependent on the monitoring approaches and associated technologies. Table 2 maps typical monitoring methods onto the asset management spectrum showing how a progressive transition from responsive to preventative practice involves a shift from the surface to the subsurface. Current practice, such as the example literature in Table 2, largely involves monitoring changes in conditions or properties that precede the morphological signs that generally trigger decisions to monitor movement or deformation Technologies to monitor condition cover a range of scales, from a sensor detecting a property time series variation at a point (or at least small volume) to non-invasive geophysical imaging methods that can provide whole asset property variations, in both space and time, potentially enabling holistic (or anatomical) condition assessment. Currently, such images inform further invasive investigation, but with increased acceptance, they could also inform design and monitor efficacy of more sophisticated, customised interventions. Improved understanding and quantification of the relationship of seismic properties $\left(G, V_{\mathrm{S}}, \rho\right)$ to engineering properties would increase acceptability and use of surface wave surveys. Early focus should include the control of moisture content on both matrix- and clastsupported fill - for example mapping seismic properties onto consistency and identifying threshold values of $G$ and $V_{\mathrm{S}}$ associated with critical shrinkage, plastic and liquid limits of finegrained materials (of various plasticities). The contribution of suction to undrained shear strength also requires further study, in particular to quantify its relationship to $G$ and $V_{\mathrm{S}}$ and their sensitivity to saturation, such as from seasonal moisture cycling. Convincing and timely delivery of this information from the research community to the geotechnical asset owners would stimulate the take-up of surface wave surveys as part of routine monitoring and management practice. 


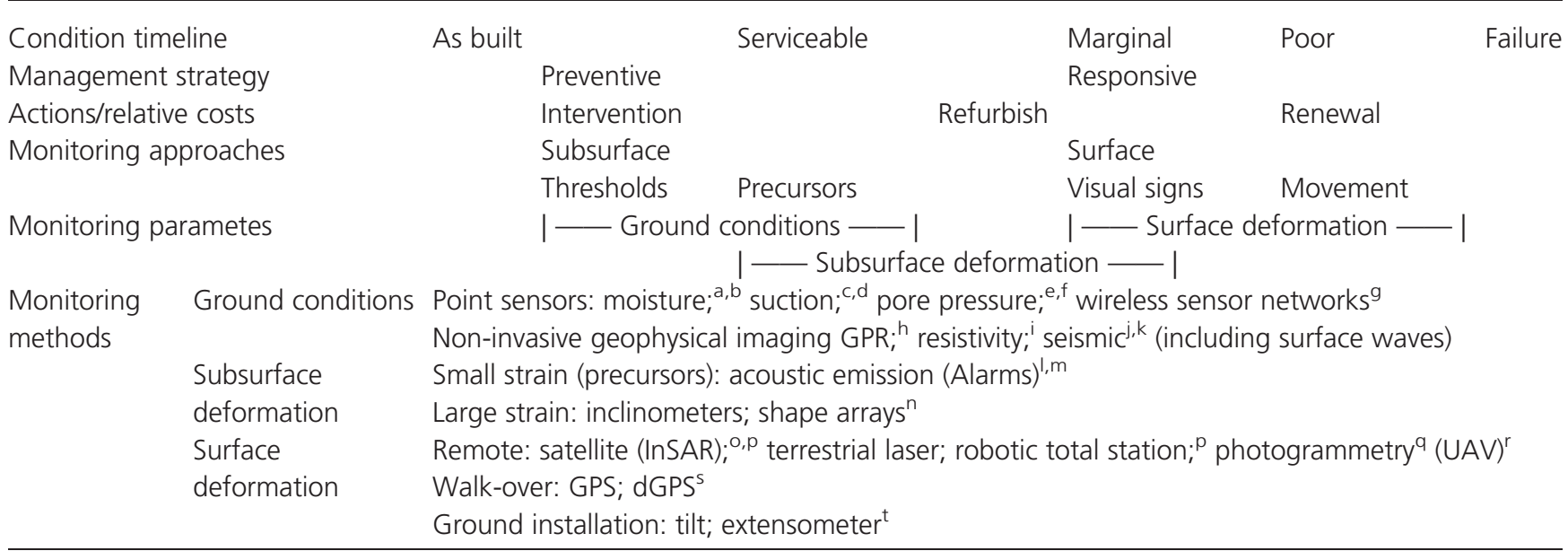

Alarms, assessment of landslides using acoustic real-time monitoring systems; dGPS, differential global positioning system; GPR, ground penetrating radar; InSAR, interferometric synthetic aperture radar; UAV, unmanned aerial vehicle

aTopp et al. (1980)

${ }^{\mathrm{b}}$ Kane et al. (2001)

'Ridley et al. (2003)

${ }^{\mathrm{d}}$ Toll et al. (2013)

eSmethurst et al. (2012)

'Lehmann et al. (2013)

${ }^{9}$ Gong et al. (2013)

${ }^{\text {h }}$ Steelman et al. (2012)

'Chambers et al. (2014)

'Donohue et al. (2013a)

kBergamo et al. (2016)

'Dixon et al. (2015)

${ }^{m}$ Smith and Dixon (2015)

${ }^{n}$ Abdoun et al. (2013)

'Scaioni et al. (2014)

${ }^{\mathrm{P}}$ Mazzani (2012)

${ }^{9}$ Bemis et al. (2014)

'Hugenholtz et al. (2015)

'Millis et al. (2008)

tWang et al. (2008)

Table 2. Common asset monitoring approaches: surface and subsurface methods mapped onto preventative-responsive spectrum

\section{Acknowledgements}

This paper is published with the permission of the executive director of the British Geological Survey (Natural Environment Research Council). The authors gratefully acknowledge the work of Richard and William Tinsley of Surface Waves Surveys Ltd, who gathered the CSW field data. The authors also gratefully acknowledge Great Central Railway (Nottingham) Ltd, Canal \& River Trust and Gloucestershire Warwickshire Steam Railway Plc for allowing access on to the East Leake, Eggborough and Laverton embankments respectively.

\section{REFERENCES}

Abbiss CP (1981) Shear wave measurements of the elasticity of the ground. Géotechnique 31(1): 91-104, http://dx.doi.org/10. 1680/geot.1981.31.1.91.
Abdoun T, Bennett V, Desrosiers T et al. (2013) Asset management and safety assessment of levees and earthen dams through comprehensive real-time field monitoring. Geotechnical and Geological Engineering 31(3): 833-843, http://dx.doi.org/10.1007/s10706-012-9569-3.

Bardet JP (1992) A viscoelastic model for the dynamic behavior of saturated poroelastic soils. Journal of Applied Mechanics 59(1): 128-135, http://dx.doi.org/10.1115/1.2899417.

Bemis SP, Micklethwaite S, Turner D et al. (2014) Groundbased and UAV-based photogrammetry: a multi-scale, high-resolution mapping tool for structural geology and paleoseismology. Journal of Structural Geology 69(Part A): 163-178, http://dx.doi.org/10.1016/j.jsg.2014.10.007. Bergamo P, Dashwood B, Uhlemann S et al. (2016) Time-lapse monitoring of climate effects on earthworks using surface 
waves. Geophysics 81(2): 1-15, http://dx.doi.org/10.1190/ GEO2015-0275.1.

Bidder FW (1900) The Great Central Railway extension: northern division. Minutes of the Proceedings of the Institution of Civil Engineers Part IV 142: 1-22.

Brees SC (1841) A Glossary of Civil Engineering Comprising Its Theory and Modern Practice. Tilt and Bogue, London, UK.

BSI (1990a) BS EN 1377-1:1990: British standard methods of test for soils for civil engineering purposes. BSI, London, UK.

BSI (1990b) BS EN 1377-8:1990: Shear strength tests (effective stress). BSI, London, UK.

Chambers J, Gunn D, Wilkinson PB et al. (2014) 4D electrical resistivity tomography monitoring of soil moisture dynamics in an operational railway embankment. Near Surface Geophysics 12(1): 61-72, http://dx.doi.org/10.3997/18730604.2013002.

Cosentini RM and Foti S (2014) Evaluation of porosity and degree of saturation from seismic and electrical data. Géotechnique 64(4): 278-286, http://dx.doi.org/10.1680/geot.13.P.075.

DfT (Department for Transport) (2014) Transport Resilience Review. A Review of the Resilience of the Transport Network to Extreme Weather Events. DfT, London, UK.

Dixon N, Smith A, Spriggs MP et al. (2015) Stability monitoring of a rail slope using acoustic emission. Proceedings of the Institution of Civil Engineers - Geotechnical Engineering 168(5): 373-384, http://dx.doi.org/10.1680/geng.14.00152.

Donohue S, Gavin K and Tolooiyan A (2011) Geophysical and geotechnical assessment of a railway embankment failure. Near Surface Geophysics 9(1): 33-44, http://dx.doi.org/10. 3997/1873-0604.2010040.

Donohue S, Gavin K and Tolooiyan A (2013a) Railway earthwork stability assessment using geophysics. In Geotechnical and Geophysical Site Characterization 4 (Coutinho RQ and Mayne PW (eds)). CRC Press, London, UK, vol. I and II, pp. 1519-1525.

Donohue S, Forristal D and Donohue L (2013b) Detection of soil compaction using seismic surface waves. Soil and Tillage Research 128: 54-60, http://dx.doi.org/10.1016/j.still.2012.11. 001.

Dunnicliff J (2012) Types of geotechnical instrumentation and their usage. In ICE Manual of Geotechnical Engineering (Burland J, Chapman T, Skinner H and Brown M (eds)). ICE Publishing, London, UK, pp. 1379-1403.

Foti S (2003) Small-strain stiffness and damping ratio of Pisa clay from surface wave tests. Géotechnique 53(5): 455-461, http:// dx.doi.org/10.1680/geot.2003.53.5.455.

Glendinning S, Helm PR, Rouainia M et al. (2015) Researchinformed design, management and maintenance of infrastructure slopes: development of a multi-scalar approach. Earth and Environmental Science 26: 1-22.

Gong C, Zeng G, Ge L et al. (2013) Design of long-distance and high-accuracy rail subgrade deformation monitoring system based on Zigbee wireless network. In Sensors, Measurement and Intelligent Materials (Kim YH and Yarlagadda P (eds)). Trans Tech Publication, Guilin, China, Parts 1-4.
Gunn DA, Jackson PD, Entwisle DC, Armstrong RW and Culshaw MG (2003) Predicting subgrade shear modulus from existing ground models. NDT \& E International 36(3): 135-144, http:// dx.doi.org/S0963-8695(02)00052-X.

Gunn DA, Nelder LM, Chambers JE et al. (2006) Assessment of railway embankment stiffness using continuous surface waves. Proceedings of the 1st International Conference on Railway Foundations, Birmingham, UK, pp. 94-106.

Gunn DA, Raines MG, Chambers JE et al. (2011) Embankment stiffness characterisation using MASW and CSW methods. Proceedings of the 11th International Conference on Railway Engineering, London, UK.

Gunn DA, Williams G, Raines MG et al. (2012) Comparison of surface wave techniques to estimate shear wave velocity in a sand and gravel sequence: Holme-Pierrepont, Nottingham, UK. Quarterly Journal of Engineering Geology and Hydrogeology 45(2): 139-160, http://dx.doi.org/10.1144/14709236/11-009.

Gunn DA, Raines MG, Williams JDO et al. (2013) Void detection using surface wave surveys. Proceedings of the 12th International Conference on Railway Engineering, London, $U K$.

Gunn DA, Chambers JE, Uhlemann S et al. (2015a) Moisture monitoring in clay embankments using electrical resistivity tomography. Construction \& Building Materials 92: 82-94, http://dx.doi.org/10.1016/j.conbuildmat.2014.06.007.

Gunn DA, Donohue S, Dashwood BAJ et al. (2015b) Earthworks ground model development using surface wave surveys. Proceedings of the XVI ECSMGE, Edinburgh, UK, 13-17 September, pp. 3541-3546.

Gunn D, Dashwood B, Chambers JE et al. (2016) Aged embankment characterisation using non-invasive geophysics. ISSHMII Proceedings of the 7th International Conference on Structural Health Monitoring, Belfast, UK, 26-27 May.

Hardin BO and Richart FE (1963) Elastic wave velocities in granular soils. Journal of the Soil Mechanics and Foundations Division 89(SM1): 33-65.

Hight DW, Bennell JD, Chana B et al. (1997) Wave velocity and stiffness measurements of Crag and Lower London Tertiaries at Sizewell. Géotechnique 47(3): 451-474, http://dx.doi.org/ 10.1680/geot.1997.47.3.451.

Hobbs PRN, Entwisle DC, Northmore KJ et al. (2012) Engineering Geology of British Rocks and Soils - Lias Group. British Geological Survey, Nottingham, UK, Internal Report OR/12/ 032 .

Hugenholtz C, Walker J, Brown O and Myshak S (2015) Earthwork volumetrics with an unmanned aerial vehicle and softcopy photogrammetry. Journal of Surveying Engineering 141(1): 06014003, http://dx.doi.org/abs/10.5623/cig2016-102. Joh SH (1996) Advances in the Data Interpretation Technique for Spectral Analysis of Surface Waves Measurements. PhD thesis, University of Texas, Austin, TX, USA.

Jones RB (1958) In-situ measurement of the dynamic properties of soil by vibration methods. Géotechnique 8(1): 1-21, http://dx. doi.org/10.1680/geot.1958.8.1.1. 
Kane WF, Beck TJ and Hughes JJ (2001) Applications of time domain reflectometry to landslide and slope monitoring. In Second International Symposium on Work Time Domain Reflectometry for Innovative Geotechnical Applications. Infrastructure Technology Institute at Northwestern University, Evanston, IL, USA, pp. 305-314.

Lehmann P, Gambazzi F, Suski B et al. (2013) Evolution of soil wetting patterns preceding a hydrologically induced landslide inferred from electrical resistivity survey and point measurements of volumetric water content and pore water pressure. Water Resources Research 49(12): 7992-8004, http:// dx.doi.org/10.1002/2013WR014560.

LCC (Leicestershire County Council) (2016) http://www. railwayarchive.org.uk/ (accessed 06/08/2016).

Mazzanti P (2012) Remote monitoring for deformation: an overview of the seven methods described in previous GINs. Geotechnical News 30(4): 24-29.

Menzies BK (2001) Near-surface site characterisation by ground stiffness profiling using surface wave geophysics. In Instrumentation in Geotechnical Engineering, H.C. Verma Commemorative Volume (Saxena KR and Sharma (eds)). Oxford \& IBH, New Delhi, India, pp. 43-71.

Millis SW, Ho ANL, Chan EKK, Lau KWK and Sun HW (2008) Instrumentation and real-time monitoring of slope movement in Hong Kong. The 12th International Conference of International Association for Computer Methods and Advances in Geomechanics (IACMAG), Goa, India, pp. 4563-4570.

Moxhay AL, Tinsley RD and Sutton JA (2001) Monitoring of soil stiffness during ground improvement using seismic surface waves. Ground Engineering 2001(January): 34-37.

Moxhay AL, Tinsley RD, Redgers RD and Gravell DC (2008) The prediction of ground settlement from continuous surface wave data. Ground Engineering 2008(September): 34-38.

Park CB, Miller RD and Xia J (1999) Multichannel analysis of surface waves (MASW). Geophysics 64(3): 800-808, http:// dx.doi.org/10.1007/s12517-016-2544-1.

Perry JG, Pedley MJ and Brady K et al. (2003) Infrastructure Embankments - Condition Appraisal and Remedial Treatment. Construction Industry Research and Information Association, London, UK, Ciria Publication C592.

Raines MG, Gunn DA, Morgan DJR et al. (2011) Refraction microtremor (ReMi) to determine the shear wave velocity structure about a mineshaft. Quarterly Journal of Engineering Geology and Hydrogeology 44(2): 211-220, http://dx.doi.org/ 10.1144/1470-9236/09-046.

Reeves GM, Sims I and Cripps JC (2006) Clay Materials Used in Construction. Geological Society, London, UK, Engineering Geology Special Publication 21.

Richart FE, Wood RD and Hall JR (1970) Vibration of Soils and Foundations. Prentice-Hall, Upper Saddle River, NJ, USA.

Ridley AM, Dineen K, Burland JB and Vaughan PR (2003) Soil matrix suction: some examples of its measurement and application in geotechnical engineering. Géotechnique 53(2): 241-254, http://dx.doi.org/10.1680/geot.2003.53.2.241.
Rix GJ (1988) Experimental Study of Factors Affecting the Spectral Analysis of Surface Waves Method. PhD thesis, University of Texas, Austin, TX, USA.

Rucker ML (2003) Applying the refraction microtremor (ReMi) shear wave technique to geotechnical characterisation. Proceedings of the 3rd International Conference on Application of Geophysical Methodologies and NDT to Transportation and Infrastructure, Orlando, FL, USA, 8-12 December.

Scaioni M, Longoni L, Melillo V and Papini M (2014) Remote sensing for landslide investigations: an overview of recent achievements and perspectives. Remote Sensing 6(10): 1-26, http://dx.doi.org/10.3390/rs6109600.

Selig ET and Waters JW (1994) Rail Geotechnology and Substructure Management. Thomas Telford, London, UK.

Skempton AW (1996) Embankments and cuttings on the early railways. Construction History 11: 33-39, http://dx.doi.org/10. 1144/GSL.

Smethurst JA, Clarke D and Powrie W (2012) Factors controlling the seasonal variation in soil water content and pore water pressures within a lightly vegetated clay slope. Géotechnique 62(5): 429-446, http://dx.doi.org/10.1680/geot.10.P.097.

Smith A and Dixon N (2015) Quantification of landslide velocity from active waveguide-generated acoustic emission. Canadian Geotechnical Journal 52(4): 413-425, http://dx.doi.org/10. 1139/cgj-2014-0226.

Socco LV and Strobbia C (2004) Surface-wave method for nearsurface characterization: a tutorial. Near Surface Geophysics 2(4): 165-185, http://dx.doi.org/10.3997/1873-0604.2004015.

Steelman CM, Endres AL and Jones JP (2012) High-resolution ground-penetrating radar monitoring of soil moisture dynamics: field results, interpretation, and comparison with unsaturated flow model. Water Resources Research 48(9): W09538, http://dx.doi.org/10.1029/2011WR011414.

Stevenson D (1886) The Principles and Practice of Canal and River Engineering, 3rd edn. Edinburgh University Press, Edinburgh, UK.

Toll DG, Lourenço SDN and Mendes J (2013) Advances in suction measurements using high suction tensiometers. Engineering Geology 165: 29-37, http://dx.doi.org/10.1016/j.enggeo.2012. 04.013.

Topp C, Davis JL and Annan AP (1980) Electromagnetic determination of soil water content: measurements in coaxial transmission lines. Water Resources Research 16(3): 574-582, http://dx.doi.org/10.1029/WR016i003p00574.

Viggiani G and Atkinson JH (1995) Stiffness of fine grained soil at very small strains. Géotechnique 45(2): 249-265, http://dx. doi.org/10.1680/geot.1995.45.2.249.

Wang FW, Araiba K, Zhang YM et al. (2008) Displacement monitoring on Shuping landslide in the Three Gorges Dam Reservoir area, China. Journal of Japan Landslide Society 44(2): 68-74.

Whalley WR, Jenkins M and Attenborough K (2012) The velocity of shear waves in unsaturated soil. Soil \& Tillage Research 125: 30-37, http://dx.doi.org/10.1016/j.still.2012.05.013.

Woodward PK, Laghrouche O, El-Kacimi A et al. (2011) Highspeed rail geotechnical issues. Proceedings of the 11th 
International Conference on Railway Engineering, London, $U K$.

Xia J, Miller RD and Park CB (1999) Estimation of near-surface shear-wave velocity by inversion of Rayleigh waves. Geophysics 64(3): 691-700, http://dx.doi.org/10.1190/1.1444578.
Zagyapan M and Fairfield CA (2000) The use of continuous surface wave and impact techniques to measure the stiffness and density of trackbed materials. In Proceedings of the International Conference, Railway Engineering 2000. Engineering Technics Press, Edinburgh, UK (CD-ROM).

\section{HOW CAN YOU CONTRIBUTE?}

To discuss this paper, please email up to 500 words to the editor at journals@ice.org.uk. Your contribution will be forwarded to the author(s) for a reply and, if considered appropriate by the editorial board, it will be published as discussion in a future issue of the journal.

Proceedings journals rely entirely on contributions from the civil engineering profession (and allied disciplines). Information about how to submit your paper online is available at www.icevirtuallibrary.com/page/authors, where you will also find detailed author guidelines. 